\title{
Dose Period Code
}

National Cancer Institute

\section{Source}

National Cancer Institute. Dose Period Code. NCI Thesaurus. Code C93557.

A coded value specifying the period during which the dose is administered. 